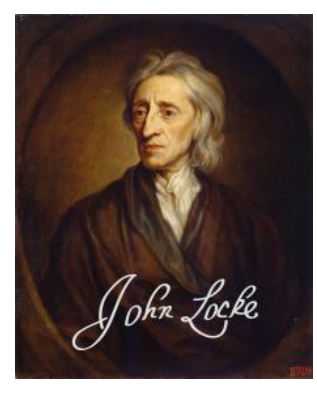

LOCKE STUDIES

Vol. 16

https://doi.org/10.5206/ls.2016.669 | ISSN: 1476-0290

Originally published: 2016

Published online: 10 FEBRUARY 2018

(C) Locke Studies, 2016

\title{
Back Matter
}

Recommended citation:

Locke Studies. "Back Matter." Locke Studies 16 (2016). https://doi.org/10.5206/ls.2016.669

For more information about this article:

https://ojs.lib.uwo.ca/index.php/locke/article/view/669

Locke Studies is published by The John Locke Society.

This is an open access article published under the terms of the Creative Commons Attribution-

NonCommercial-ShareAlike 4.0 International license, which permits use, distribution and reproduction in any medium, provided the original work is properly cited and shared under the original license. 


\section{SUBSCRIPTION RATES}

\section{Locke Studies (2001-)}

The price of Locke Studies is $£ 32$, or US $\$ 64$, or $€ 54$. The journal may be obtained through agents or directly from the Editor, as a single volume or on regular subscription. Vol. 1 (2001) and the subsequent volumes are still available (at this price).

Individuals may obtain Locke Studies at a concessionary rate directly from the Editor, at the address given inside the front cover, by sending a payment of $£ 16$, or US $\$ 32$, or $€ 27$ per volume.

Prices include postage by surface mail (airmail to Europe). Elsewhere, airmail delivery is $£ 4$ or $\$ 8$ extra. Cheques should be made payable to 'Locke Studies'.

\section{The Locke Newsletter (1970-2000)}

No. 31 (2000), 264 pp., including a complete index to the previous thirty years (69 pp.), is available on the same terms as Locke Studies (see above).

Previous issues of The Locke Newsletter can be obtained either through agents or directly from the Editor, at the former price of $£ 17$, or $\$ 34$, or $€ 30$, which includes postage. (The concessionary rate for individuals, buying directly from the Editor, is $£ 9.50$, or $\$ 19$, or $€ 17.50$.) Nos. 1-30 (1970-99) are all available, though some early issues (usually nos. 1-8 and 16) can only be supplied in the form of xeroxed sheets. The contents of nos. 1-25 can be seen from the triple index in no. 25 (1994), or on the website (www.luc.edu/philosophy/LockeStudies). 
3 The Role of Appropriation in Locke's Account of Persons and Personal Identity

RUTH BOEKER

41 Locke on Knowledge of Existence NATHAN ROCKWOOD

69 Physica in John Locke's Classifications of the Branches of Knowledge and Adversaria GIULIANA DI BIASE

167 Peter Anstey on Locke's Natural Philosophy JONATHAN CRAIG WALMSLEY

195 The Wider World of Locke's Landlady, Rabsy Smithsby BRIDGET CLARKE

215 Some Reflections on Critical-Text Editing: The Case of Hobbes's Leviathan IAN HARRIS 


\title{
LOCKE STUDIES
}

\author{
EDITOR
}

Timothy Stanton

ADDRESS FOR SUBSCRIPTIONS AND CORRESPONDENCE

Dr. Timothy Stanton, Editor, Locke Studies, Department of

Politics, University of York, York YO10 5DD, United Kingdom (email: editor@lockestudies.org)

Published by Timothy Stanton

Typeset by the Editor

Printed by Design \& Print Solutions, University of York

ISSN 1476-0290

(C) Timothy Stanton, 2016 